\title{
Historiographical review of the current debate on Ethiopian land tenure system
}

\author{
Binayew Tamrat Getahun \\ Department of History and Civics, School of Humanities and Law, Adama University-Ethiopia.
}

Received 10 November, 2014 Accepted 19 January, 2015

\begin{abstract}
During the period of the Transitional Government of Ethiopia (TGE), that took power following the downfall of the Socialist Derg Government, the issue of land tenancy has hotly debated among politicians. At the ratification of the 1995 Constitution, though the ruling party, EPDRF, made attempt to formally end this debatable agenda by formally enshrining state ownership in the 1995 constitution, the ruling party is not yet able to conclude this controversial and thorny issue in its favour. Since there have been people and dozens of parties arguing for private land owner ship, the debate on the issue continues till this day. Ethiopia's rural land tenure system in particular has become bone of contention. (Mulat et al., 1998; Hoben, 2002). Land tenancy presupposes land ownership.' And the dispute about the Ethiopian land tenure system is largely between those in need of changing the existing state ownership tenure and the EPRDF led government of Ethiopia. Currently, the continued debate in the state -private land ownership dichotomy has kindled the interests of scholars in various fields. Different scholars and parties are writing and debating on the subject. In this article an attempt is made to remark and analyze the major ones.
\end{abstract}

Key words: land tenure, resource management, landownership, peasant, debate, tenure security, eviction and land fragmentation

\section{INTRODUCTION}

Ethiopia is predominantly an agrarian state. As in any other states inhabited by agrarian society, land in Ethiopia has been the major means of production and livelihoods. Land is the major asset in both traditional and modern societies.i. It has been a crucial means of production for the rural society and for the ruling elite.ii For rural society land is very valuable because its entire life is depended on land. Land served the people as its abode; as a means of production and as symbol freedom. ${ }^{\text {iv }}$ Land was taken as symbol of freedom because in the pre 1974 revolutionary Ethiopia, only those people with land use right or rist land were considered as a liberated or free. People without rist land, on the other hand, were considered either as slaves or serfs for landowners. Moreover, it was highly valued by the society as abode of ancestors. For the rulers of the country land has been the basis of their political and economic power. Land was/ is equally important to the ruling elite as political instrument to manipulate the people. ${ }^{v}$

Regardless of the centrality of land in the social,

\section{E-mail: benayew2002@yahoo.com.}

Author agree that this article remain pemanently open access under the tems of the Creative Commons Attribution Lic ense 4.0 Intemational License 
economic and political institutions of the country, systematic land tenure studies to understand the roots of the problem was generally scant until recent past. It is, however, not to overlook the comment and notes left by European travelers and missionaries. In the $17^{\text {th }}$ century, Jesuit missionaries M. Allmeida and Pedro Paez wrote an account describing how tribute was collected and how powerful the Ethiopian emperors were. In the same century, the German historian Job Ludolf commented that the Abyssinian emperor was valiant who had power over the land of the country. ${ }^{\mathrm{vi}}$

In the $18^{\text {th }}$ century the Scottish traveler and historian James Bruce and the French traveler Arnold d' Abbadie contributed a lot to the subject. A great number of the $17^{\text {th }}$ and $18^{\text {th }}$ century missionaries and travelers that came to Ethiopia for different purposes had also written accounts and notes on the contemporary land tenure. The works of these missionaries and travelers have one thing in common that what they had written on land tenure is routine, general and specific. ${ }^{\text {vii }}$

In the $19^{\text {th }}$ century catholic and protestant missionaries that came to Ethiopia for missionary work as well as travelers, diplomats and other Europeans left important comments about land related issues. For instance as the British traveler Henry salt described Ethiopia as feudal state, Plowden a British consul and one of the intimate friends of the Ethiopian Emperor Tewdros II(r 1855-1869) in Ethiopia, left us an important report about emperor's intended land reform. ${ }^{\text {viii }}$ Although fragmented and specific in nature such accounts of expatriates give highlights on the contemporary land system of Ethiopia.

It was however with the coming of the Italian scholars in the late $19^{\text {th }}$ century that land tenure studies were started in a systematic and in a new fashion. The Italians, Ruffilo Perini and Conti Rossini, are noted for giving Ethiopian land tenure studies new life. Based on Extensive field work and investigations they had attempted to reconstruct the land tenure history of the country. Ruffilo Perini came to Eritrea as military officer and wrote different books on land and related subjects, based on his research findings, largely for the purpose of easing colonial administration. Although he was a military officer, his works earned Perini a scholarly status and recognition. Conti Rossini, a historian from the same country, mainly based on manuscripts he found and collected in Axum Tseon Church of Ethiopia, produced and published many books on land tenure. Another Italian scholar, Gudini, came up with many works and was mainly relied on Amharic manuscripts to write on land tenure and related issues. These three Italian scholars whose arrival dated back to the pre Italian occupation period (before 1935) undertook rigors research and produced different works mainly to minimize problems related to pave the way for colonizing Ethiopia and policy making for land administration in Eritrea (Shiferaw, 2001).
Some of the early $20^{\text {th }}$ century Ethiopian intellectuals had also made a significant contribution in land tenure studies. Gebre Hiywot Baykedagne and TekleHawaryat Tekle Maryam, for instance, tried to reflect the contemporary land tenure system with liberal and critical eyes. As cited in one of Bahiru Zewde's works, the two scholars wrote commenting and criticizing the early $20^{\text {th }}$ century Ethiopian land tenure system. By criticizing the inherent problems of the Ethiopian land tenure system, they advocated for change of the system. In this regard, Gebre Hiywot, who had strongly opposed the concentration of land in the hands of few land lords, underlined and suggested for equity. At the same time, however, he defended the right of private property and suggested to the then authorities to respect the right of land owners to sell their land (Bahiru, 2002).

Bejerond Tekle Hawaryat Teklemaryam, who drafted the first Ethiopian written constitution of 1931, was more radical in opposing the imperial land tenure system. Like Gebre Hiywot, his argument emphasized on equity in accessing land. He argued that since it was created for its entire abode for both men and animals; land should be accessed and used equitably. But Tekle Hawaryat made it clear that he was not an advocate of socialism or capitalism. Rather what Tekle Hawarayat wanted was land to be redistributed on the basis of traditional and historical experiences of the country. ${ }^{\text {ix }}$

Largely for the consumption of government's effort for reform and land administration traditional writers like Mahitama Selasie WoldeMesqal were also immersed with the task of reconstructing the history of the country's land tenure. In his one of his works, Mahitama Selasie WoldeMesqal attempted to reveal the system of land tenancy and the way how taxes were collected. Needless to say his work was compiled based on other sources like oral information. In addition, serving as a courtier, Maheteme Sellasie himself was one of the top officials of Emperor Haile Selassie I (r1930-1974). As such he was familiar with all what was going on in the imperial administration including land tenure system. As part of the imperial administrative system however, he lacked the courage to criticize and to reflect real situation in the country. ${ }^{\times}$During the Italian occupation of Ethiopia (19351941), the traditional land tenure system was disrupted. It is a known fact that the fascist Italians, though unsuccessful, embarked on land appropriation. By snatching the gult and rist lands of the Ethiopians, the Italians distributed it to their loyal servants. In this process the nobility and other land owners who had been closely associated with the ruling class became victims of the Italian land grabbing policy. By doing so the Italians seriously weakened and in some parts of Ethiopia they totally eliminated the land owning nobility. According to Habtamu Mengistie this event can be taken as a turning point in the history of lord tenancy relationship and hence in the whole land tenure system in Ethiopia. ${ }^{x i}$ 
In the post liberation era scholars both foreign and Ethiopian, armed with skills of research and specialized with trainings in history, anthropology and other social sciences, joined the field of land tenure studies. From Ethiopia historians such as Tadesse Tamrat and Merid Wolde Aregay, both of them were professors in the history department of Addis Abeba University, and Donald Crummy a well known American historian, who had served in Ethiopia for at least a decade in Addis Abeba University, had a very significant contribution in land tenure studies. Three of them were embarked on rigorous field work and succeeded in unearthing seemingly forgotten Geez sources from all corners of the country. xi

Largely based on sources collected from religious and secular institutions in different parts of the country, the three historians produced different works which they later published in the form of books and as articles in well known international journals. While Taddese's Classical and famous work, "Church and state in Ethiopia" gives general highlights on land tenure system and related institutions of medieval Ethiopia from 1270 to 1527, Mered Weld Aregay's different articles dealt with land and related issues covering the succeeding two centuries xiii Likewise, Donald Crummy contributed to land tenure studies in various ways. His presence in Addis Ababa University provided Crummey a good opportunity to collect and assess sources from different churches and monasteries of northern Ethiopia. Largely relying primary sources such as manuscripts and first hand information, Crummy wrote a number of historical works the most important of which, "Land and Society in Christian Highland Kingdom from $13^{\text {th }}$ to $20^{\text {th }}$ century ." is not only his full fledged work but also it covers a large span of time in land tenure issues. In his book Crummey made an impressive investigation regarding the existed relationship between the land propertied institutions and the ordinary society. In addition to his systematic assessment of the complicated land tenure issues of Ethiopia from $13^{\text {th }}$ to $20^{\text {th }}$ century, Crummey recognized alqenet as new institution in association with the church in the $18^{\text {th }}$ century. Thus through exhaustive use of his sources, critical analyzed and looked the different dimensions of land tenure and changed the static style of writing in the historiography of Ethiopian land tenure studies. ${ }^{\text {xiv }}$

Before Donald Crummey's outstanding work, about four monographs were produced in a series of land tenure studies. The first and the second were the works of G.W.B. Huntingford and H.S Man both of which were compiled to ease the task of land administration. Huntingford's work is, however, a mere collection of land charters of Northern Ethiopia. From all corners of north Ethiopia, Huntingford disclosed Land charters granted to religious and secular institutions both by kings and other nobles of Ethiopia. Actually, the task of collecting and translating numerous land Charters from Ethiopian to English language with new patterns of arrangement by itself is not an easy task. ${ }^{\mathrm{x}}$

The second monograph as explicitly stated by Richard Pankhurst was written on the basis of extensive field works in one of the sub districts of North Shewa. And the third monograph in the series belonged to Richard Pankhurst, a historian from Great Britain and well known for writing on many other themes of Ethiopian history. In his work published in 1966, R. Pankhurst made an attempt to assess and analyze Ethiopian land tenure issues chronologically from the time of Axum right up to the $20^{\text {th }}$ century. However, his work is too ambitious and lacks deep analyses of the issues raised by him. Moreover, other than putting evidences as string of events in a report form, Pankhurst make little effort to look into what is implied in the evidences with critical eyes. In addition, the author excessively relied on accounts of Europeans. ${ }^{\text {xvi }}$ From these points of view it is possible to safely argue that $\mathrm{R}$. Pankhurst did not use sources wisely and exhaustively. Probably, he may refuse to suffer from painstaking task of collecting and interpreting rich varieties sources in Ethiopian language.

Alan Hoben, an American Social Anthropologist who came to Ethiopia in the last years of 1960s, embarked on field works in rural areas. Largely based on original and fresh data he produced dozens of articles and books including the fourth monograph that was published in 1973. Like Crummey, Hobben outshined other expatriate researchers in many ways. First of all his works are almost totally relied on grass root level field works. Secondly, he critically looked into property regimes with concomitant institutions as well as societal values in a bottom -top approach. Moreover, he brought the method of social anthropologists in to the field of land tenure studies. However, Hoben's studies remain restricted in narrow areas especially in Damot of Amhara region, Ethiopia. ${ }^{\text {xvi }}$

Like Allan Hobben, Dessalegne Rahmato dedicated himself to land tenure studies for three decades. From his large number articles and a book produced on land tenure and related issues, the most important and influential one is the Agrarian Reform of 1984. As a source his book is important because it furnishes scholars in the field with fresh data. Moreover, by giving new insights on the field of land tenure studies, Desalegne's books arouse the appetite of other new researchers. $^{\text {xviii }}$ The works of the two scholars, Hobben and Dessalege, are among the major sources of information to realize the background of the subject under question.

\section{THE CONTEMPORARY DEBATE ON THE ETHIOPIAN LAND TENURE SYSTEM}

Generally, different views and rational arose in relation to 
the current debate regarding land ownership. Political scientists, social anthropologists, economists, government officials and to some extent journalists are involving as major actors in the ongoing debate. From social anthropologists, Allan Hobben, who has been contributing works in articles, traced the origin of the current debate on issue of landownership in Ethiopia to post Derg period. According to him the controversy started just before the ratification in 1994-95 of the Constitution of the Federal Democratic Republic of Ethiopia/FDRE/. He further elucidated that at the beginning the debate was between political parties. The Ethiopian Peoples' Revolutionary Democratic Front /EPDRF/ leadership, like the preceding Socialist regime, favoured state-public ownership of land. Most of the opposition parties have been arguing land to be owned privately. At the end, state ownership was decided and legally stipulated in to the 1995 constitution. In the FDRE constitution, article 40 sub article 3 , it is stated that 'the right of ownership of rural and urban land as well as of all natural resources, is exclusively vested in the State and in the peoples of Ethiopia.' Soon after adoption of the 1995 constitution, the EPDRF leadership officially declared that the issue has been constitutionally resolved. ${ }^{\text {xix }}$ The Ethiopian government continues to support state ownership of land whereby only usufruct rights are granted upon landholders. Usufruct rights prohibit land holders the right to sell or mortgage it.

However, following the 2000 Parliamentary election the issue resurfaced and the debate that revolved on the axis of state- private land ownership dichotomy began to be escalated than ever before. The ruling party EPRDF, its officials and some scholars continue their argument in support of state ownership. Rival political parties, Western oriented economic advisors, some donor agencies and a large number of academicians opted striving to private ownership. ${ }^{x x}$

Each of the scholars, who belonged to those who are arguing in support of private land ownership are not unanimous in their argument and justification. Dessalegne Rahmato, one of the leading scholars debating in support of privatization, for instance, has identified land tenure insecurity, land fragmentation, land management as major rationale for argument behind the state -private

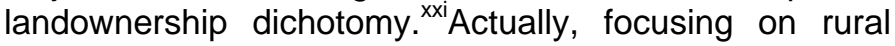
land tenancy, the debate revolves around these issues. The rival groups made themselves busy striving to resolve these land ownership related issues for the rural society.

One issue of debating fragmented land, as reflected in their works, is taken by contending groups as unviable to agricultural development. Each of the two contending groups realized that fragmented plots of land is not viable to agricultural development and hence they, though with slight difference, aspired to do away with fragmented plots of land. One of the supporters of private ownership
Bruce (1993:23) commented that land fragmentation leads to inefficient use of time and farmers' energy going between parcels of land ${ }^{x \times i i}$ and implicitly suggests fragmented land holding system to be eliminated. The EPRDF led government officials, the main advocates of state ownership, accepted Bruce's idea that the government is now working to put an end to land fragmentation. Moreover, they elaborated that since agricultural development on the plots of farm lands is unviable, the government will refrain from making land redistribution in the future. This is because as stated in its rural development strategy, further land redistribution will drastically reduce the size of plots in to smaller slices of land. Instead of taking land from individual peasants with use rights to youth residing in rural Ethiopia, the government encouraged voluntary resettlement program as a short remedy to land fragmentation. ${ }^{x \text { xii }}$

Proponents of Privatization and State ownership accept land fragmentation as a problem, what led the two in to disagreement is the way how to embark upon the problem. Individualists totally reject EPRDF's measures which it took as a strategy to deal with the issue. For them the best solution to deal with the issue and for intensification of agriculture is making farmlands to be consolidated into higher size holdings. ${ }^{\text {xiv }}$ The explicit implication of this argument is that the government should allow land to be concentrated and consolidate in the hands of private owners. Actually, there is slight difference even among proponents of Private ownership. Desalgne for instance departs from the group and stood in support of fragmented land. He expounded that purposefully created fragmented farm lands are in some cases useful to cope up with natural and ecological problems. Basing his argument on experiences, Desalegne justified that when peasants' farm land consolidated in one area natural calamities like snowstorm can devastate all their crops and he suggested plots to be kept. ${ }^{\mathrm{x} v}$

Regarding land tenure insecurity, supporters state ownership argue that as long as peasants use and develop their plots of land properly, no one can dispossess/evict/ them from their holding. By citing FDRE Constitution (article 40 sub Article 4), they elaborate that peasants have bestowed with full and legal right over their land to use and to improve it and that the state protects them from eviction. Moreover, the ruling party and its supporters defended that peasants' right for land are guaranteed by granting ownership certificates. To strengthen their sense of ownership to their land, peasants have been registered and received land holding certificate. Moreover, the EPDRF led government asserted that the certificate provides peasant households with robust land property rights. ${ }^{x \times i}$

Proponents of private land ownership, on the other hand, argue that the current land tenure policy does not give peasants tenure security. In justifying this they 
expounded that the government is taking peasant land away and redistributed it mostly to its supporters. And peasants are always apprehensive of land redistribution, which makes them lose confidence to work on and to improve/develop/ their plots. In this regard, supporters of this group mentioned the land redistribution of Amhara region of Ethiopia undertaken in 1996-1997 as a justification for their argument. The EPDDF led government claimed that the land redistribution was made to redress the unfair land redistribution and possession made by the Derg local officials and cadres who were blamed for taking the fertile farmlands for themselves. However, its implementation was contradictory to the constitution's provision and to EPDRF leadership rhetoric. Obviously, the government used land redistribution not for the sake of achieving equity as intended but rather as a political weapon to assault what it called "remnant bureaucrats of Derg". ${ }^{x x v i i}$

For advocates of private land ownership, the solution to the problem of tenure insecurity is providing peasants unrestricted access and right to use their land in whatever way they liked. This right should include the right to use land as collateral to exchange and sale. Such an restrict right, they added, will enable peasants to confidently and properly manage their land as a result of which land degradation can be minimized. ${ }^{x \times v i i i}$ In many of his articles which he wrote in support of land privatization, Desalegne concluded that the only way to provide tenure security for peasants is land privatization. Based on empirical reasons, the same scholar made the government's fear of consequential dangers of allowing land for sale groundless. Desalegne's justification for this argument is that except in some rare cases peasants do not sell their land. And even in such rare cases it is possible to make land transaction uneasy by means of new legislation. ${ }^{\text {xxix }}$ At other instance Desalegne stood in support of land sale. The same author criticized the government's conservative position for prohibiting emergence of dynamic land marketing in Ethiopia. Desalegne does not give detail explanation on how the current land system inhibits land market dynamism. ${ }^{x \times x}$ But his own position regarding land sale is far from being clear. In one occasion, he appears to assure that peasants never endanger their life caused by land sale; on the other, he blamed the government for prohibiting land sale.

As clearly elaborated in its Rural Development Strategy, the EPDRF led government has strongly opposed the idea of privatization as well as marketability of land. Accordingly, if it is subjected to sale, mortgage and other means of exchange, land will be concentrated in the hands of a few urban based unscrupulous capitalists. The state further expressed its apprehension that privatization of land may lead peasants to eviction and other disastrous socio political and economic consequence. ${ }^{x \times x i}$ Hence considering itself as defender of the rural society and the peasants in particularly, the EPDRF strongly opposed the idea of private land ownership and land sale.

The advocates of private ownership for their part strongly objected the governments' justification. Rejecting the state's rhetoric as defender of peasants, they argued that even though the government kept the land under its control to address the problem associated with peasants' eviction "landlessness refused to disappear" This is because the state itself has involved in the process of making peasants landless. They asserted that the government itself has been snatching and evicting peasants living in the semi urban areas. ${ }^{\text {xxii }}$

In their struggle for private ownership the issue of land sale is invariably taken by economists and western oriented advisors as a central agenda. They criticized the state's effort to move towards market economy while controlling land. They protested that "One cannot move towards a market economy while keeping land-the most vital means of production on agricultural economy outside the operations of the market" ${ }^{\text {xxxiii }}$ However, the EPRDF led governments has aspired to keep its grip on land related issues. As a response to their strong desire to make land a private property and saleable as a commodity, the former EFDRE prime Minister as cited in Samuel (2006:78) defended that " land privatization in Ethiopia would take place only over the EPRDF's 'dead body'." Moreover, EPRDF and top government officials repeatedly notified that debating on constitutionally resolved issue is a 'sterile' argument. ${ }^{\text {xxiv }}$

There are some scholars who stood in support of state ownership position. Fantu Cheru and Marquardt, for instance, proposed land to be under state for equity reasons. Like the EPDRF led government, Fantu strongly defended land privatization. In justifying his position, Fantu expounded that reinstating a western style property right and land selling would led the country to its pre1974 situation during which large number of peasants were made to be landless and forced to join the urban destitute. Moreover, he suggested state ownership for equity reasons. For him land has to be under state ownership so that it could be distributed to the rural people equitably and land tenure security, he added, could be maintained through legislation. ${ }^{x \times v}$ With slight difference to Fantu, Marquardt argues in support of state ownership. In his justification,

Marquardt expounded the existence of governments' ultimate power overland even in countries where privatization is well established and implicitly supported the government's position. ${ }^{\text {xxvi }}$

Very few writers try to search ways of minimizing the controversy by forwarding some options that narrow the polarized positions in between pro -private and pro-state ownership debate. Deininger can be taken as a case in point. In his report, Deininger suggested land use rights to be granted to land occupants or users in a formal long 
term lease. According to him, if long term use rights are given the disparity between state ownership and private ownership could be narrowed and users could be more secure in their tenure. The experiences of other countries like China, Israel, and Vietnam are cited as examples that in these countries while land was owned by the state by means of long -term lease land tenure security and investment promoted. .xxvii

The other controversial issue in the subject under discussion is land administration and its resource management. Allan Hoben criticizing the EPDRF's top down authoritarian approach forwarded an optional one by the name of "Frame work approach"xxxviii Another leading promoter of land private ownership, Dessalegne Rahmato, has his own approach known as Associative ownership. ${ }^{\text {xxix }}$ While the former gives emphasis to enhancing popular participation by way of bottom-up decision making on land and resource management, the latter give priority to defending 'outsiders' from sharing peasants' rural land. The term 'outsider' implies others who compete for the lands of certain peasant community both from nearby and distant other areas. Both of the approaches, however, have no room for investors and hence no agricultural intensification with involvement of capitalist investors. Moreover, in both cases what role the government should play in land and resource management is not clearly elaborated. Apparently, the two approaches/options focused on holding back government's interference which cannot be practical elsewhere.

As it is possible to look from the literature from land tenure related issues more emphasis is given to state private ownership dichotomy. And the contending parties are criticized for focusing on a single land tenure issue and for failing to listen to what the rural society pastoralists and peasants- say about the issue under discussion. The EPRDF considering itself as champion of the rural society strictly took state ownership of land as a guarantee for peasants and pastoralist tenure security; the rival political parties, on the other hand, argue that only giving the rural society full authority on their land as a private property will make them more secured and confident to improve and manage farm land (Yigremew, 2001), The protagonists of the current debate are still busy either trying to persuade rivals to accept their rational or in making effort to bring the debate to an end in their own way. However, the main stakeholder of the issue, the rural society, other than being told what has been decided, has not yet got involved in choosing what is better to it. Therefore in some cases the rationale and assumptions of the contending groups discovered being invalid for each position fails to reflect the reality around the rural society. Some researchers confirmed that both of the contending parties debated on the issue of land ownership largely based on either calculated assumptions or political ambitions. Accordingly, during the field work as cited in EEA/EPRI (2002:40-49) when randomly selected farmers from different regions of the country asked " if you are given the right to use your current land as you wish, would you sell it partially or totally?" Over $90 \%$ of them were said to have responded "No we do not sell." Out of them some responded that in whatever conditions they will not sell their lands making EPRDF's hitherto upheld 'fear' regarding land sale groundless. On the other hand, in relation to assumptions of pro- private land ownership, the question asked was "Is the current land tenure system good or bad?" As response to this, the majority of the farmers particularly that of Afars and Somali responded "it is good" supporting the current land tenure system. ${ }^{\mathrm{xl}}$

Obviously, this case has two obvious implications. On one hand, the contenders, on both sides of the argument, are more likely reflecting their own interest and ideologies without fully investigate the interests of rural society. On the other hand, each of them may not fully understand the adverse effect of deciding land policies without letting the concerned section of the society. Thus as Allan Hoben rightly commented it will be better if contending parties listen what the people say and take into account the social ,cultural and historical contexts of the society before designing and revising land policies and strategies. ${ }^{\text {xi }}$

\section{Conclusion}

From our sources used to reconstruct this article it is possible to realize that debates on land ownership are variations on the same theme. For a country inhabited by different communities at different stages of development and with diversified socio-cultural values and political experiences a single state-private choice will not be suitable. What is recommended as optional tenure system for such a country is flexible and adaptive arrangement that will go with different experiences and dynamics of the subject in question. If the contending parties aspired the land policy to serve as basic instrument to effectively address issues tenure security and proper land use and development, the contending parties by disregarding personal assumption and political interest needs to reach at a genuine decision for an alternative land policy based on pre agreed principles or criteria.

Government's role has to be restricted to participatory land law making and overseeing its proper enforcement and the task of land and its resource management may be left to democratically elected land committee to be accountable to the electorate community. By doing so the right of land ownership will be bestowed to the community and idle lands can be distributed for the wider needs of the people and development schemes of the government. 


\section{Conflict of Interests}

The author has not declared any conflict of interests.

\section{REFERENCES}

Bahiru Z (2002). Pioneers of Change in Ethiopia; the Reformist intellectuals of Early $20^{\text {th }}$ century Ethiopia, Addis Abeba university press: Addis Abeba.

Bruce JW, Allan H, Desalegne R (1993). After the Derg: An Assessment of Rural Land tenure issues in Ethiopia (Institute of Development and Research and Land Tenure Centre.

Desalegne Rahmato (2006). 'From Heterogeneity to homogeneity Agrarian class Structure in Ethiopia since the 1950s.In Desalegne and Taye(ed.)Land and the Challenges of Sustainable Development in Ethiopia, Conference Proceeding (Forum for Social Studies :Addis Ababa.

Ethiopian Economic Association / Ethiopian Economic Policy Research Institute/EEA/EEPRI (2002). Land Tenure and Agricultural Development in Ethiopia (United Printers, Addis Ababa.

Fantu C (1994). Designing Structural Adjustment program; Reconstruction, Rehabilitation and Long term Transformation. in Abebe Zegeye and Pausewang, Siegfred (eds.) Ethiopia in Change; peasantry ,Nationalism and Democracy, British Academic Press: London.

FDRE Rural Development Strategy,1998

Habtamu M (2011). Land Tenure and Agrarian Social Structure in Ethiopia, 1636-1900, PhD dissertation (University of Illinois at Urbana-Champaign, Urbana.

Hoben A (1973). Land Tenure among the Amhara of Ethiopia, the Dynamics of cognates' Descent, Chicago University press, Chicago.

Hoben A (2002). "Ethiopian Land Tenure Revisited: Continuity, Change and Contradictions" In: Workeneh etal (eds.).Current Issue issues on Land Tenure in Ethiopia; Access, Food production and Natural Resource Management, Proceedings of the workshop on Current Issue on land Tenure in Ethiopia,(Institute of Development Research (IDR) Addis Ababa University,2002), 25.

Huntingford GWB (1965). The Land Charters of Northern Ethiopia, the Institute of Ethiopian Studies and the Faculty of Law of Haile Selassie I university in association with Oxford University Press, Addis Abeba.

Mahtema Selassie Wolda Masqal (1957). "Land Tenure and Taxation from Ancient to Modern Times: the Land System of Ethiopia" Ethiopian Observer.

Marqnardt MA (2006). "Global Experiences in Land Registration and Titling." In Solomon Bekure etal (eds.) Standardization of Rural Land Registration and Cadastral Survey Methodologies in Ethiopia, Proceedings of a National Conference, Addis Ababa.

Mulat D, Kelly V, Jayne TS, Said A, Le Vallee JC, Chen H (1998). Agricultural market performance and determinants of fertilizer use in Ethiopia. Working Paper 10. Grain Market Research Project. Addis Ababa, MEDaC.

Negarit G (1995) Constitution of Federal Democratic Republic Ethiopia(FDRE) 1 year, No.1, Addis Abeba.

Pankhurst Richard (1966). State and land in Ethiopian History, the Institute of law of Haile Selassie I university in association with Oxford University: Addis Ababa.

Shiferaw B (2001). "A Historical Outline of Land Tenure Studies" In: Bausi (ed) Anthropological Document on 'Rim' in Ethiopia and Eritrea, Torino, L, Harmatan Italia.

Tafefese O (2006). "Ethiopia: Politics of Land Tenure Under Three Regimes: a Carrot and Stick Ruling strategy" in Alexander, Kassahun and Yonas (eds) Ethiopia Politics, Policy Making and Rular Development.

Temesgen G (2013). "Peasants, land reform and property right in Ethiopia: The experience of Gojjam Province, 1974 to 1997", J. Afr. Stud. Dev. 5(6):145-156.

Yigremew A (2001). "Some Queries about the Debate on Land
Tenurein Ethiopia". In Mulat and Tassew (eds) proceedings of the Tenth Annual conference on Ethiopian Economy, Ethiopian Economic Association/ECA.

${ }^{\mathrm{i}}$ Ibid,EEA/EEPRI(2002),vi

${ }^{i i}$ Ethiopian Economic Association / Ethiopian Economic Policy Research Institute, / EEA/EEPRI hereafter) Land Tenure and Agricultural Development in Ethiopia (United Printers, Addis Ababa, 2002), VI-vi

iii Svein Ege, Land Tenure Issues in Northern Shewa: Tenure issues in different Agro Ecologies. In Dessalegn (eds) Land Tenure and Land Policy in Ethiopia after the Derg, Proceeding of the Second workshop of the Land Tenure Project,( the University Of Trondheim, Center for Environment and development Unit, 1994),163.

iv Ethiopian Economic Association / Ethiopian Economic Policy Research Institute / EEA/EEPRI, Land Tenure and Agricultural Development in Ethiopia (United Printers, Addis Ababa, 2002), VI.

v Tafefese Olika, "Ethiopia: Politics of Land Tenure Under Three Regimes: a Carrot and Stick Ruling strategy" in Alexander, Kassahun and Yonas (eds) Ethiopia Politics ,Policy Making and Rular Development ,(2006),1-5; In the Pre-1974 Revolutionary Ethiopia as Rist land was inherited from fathers and forefathers to descendants and in so long as the holder pays tribute to the concerned authority no one could take away the rist land of each peasant.

${ }^{\mathrm{vi}}$ Richard Pankhurst, State and land in Ethiopian History, (the Institute of law of Haile Selassie I university in association with Oxford University: Addis Ababa, 1966), 1-5.

vii Shiferaw Bekele, “A historical Outline of Land Tenure Studies” In Bausi (ed) Anthropological Document on 'Rim' in Ethiopia and Eritrea,( Torino ,L, Harmatan Italia ,2001),12.

viii Richard Pankhurust,(1966),10-24.

${ }^{\text {ix }}$ Ibid,

${ }^{x}$ Mahtema Selassie Wolda Masqal, "Land Tenure and Taxation from Ancient to Modern Times: the Land System of Ethiopia” Ethiopian Observer (1957) I, 283-288.

xi Habtamu Mengeste, LAND TENURE AND AGRARIAN SOCIAL STRUCTURE IN ETHIOPIA, 1636-1900, PhD dissertation ( University of Illinois at Urbana-Champaign ,Urbana,2011),212;Binayew Tamrat, A History of Zege Peninsula,1902-1991,(M.A Thesis, Addis Ababa University 2009) ,39 xii Tadese Tamrat's <Church and State in Ethiopia,12701727,Oxford:Clanderndon Press(1972)' Donald Rummy's 'Land and Society in Christian kingdom of Ethiopia from $13^{\text {th }}$ to $20^{\text {th }}$ centuries, Addis Ababa: Addis Ababa University Press' and Merid Weld Argay's works, among other themes, deals on land tenure issues. The works of the three history professors relied mainly on archival sources in position of the Ethiopian Orthodox Church.

xiii Before its gradual replacement by Amharic after the $19^{\text {th }}$ century, Geez was an official language of the Christian highland Kingdom of Ethiopia; Shiferaw Bekele, (2001),28-30.

xiv Ibid, sheferaw (2001)28-31.

${ }^{\mathrm{xv}}$ Richard Pankhurst,(1966),V; G.W.B. Huntingford , the Land Charters of Northern Ethiopia( the Institute of Ethiopian Studies and the Faculty of Law of Haile Selassie I university in association with Oxford University Press ,Addis Abeba,1965),1-25.

xvi Richard Pankhurst ,(1966),v-75; Though British by birth, R. Pankhurst is one of the outstanding Historians who dedicated much of his effort, resources and time in reconstructing Ethiopian past and wrote dozens books on various themes of Ethiopian history. But his works almost totally relied either on accounts of travelers and writings of diplomats.

xvii Allan Hobben, Land Tenure among the Amhara of Ethiopia, the Dynamics of cognates’ Descent,( Chicago University press,Chicago,1973),1.

xviii Shieferaw,(2001),37-44;Dessalegne Rahmato, Agrarian Reform in Ethiopia, Scandinavian Institute of African Studies, Uppsala, 1984.

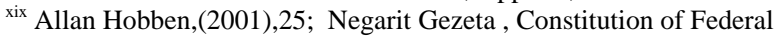
Democratic Republic Ethiopia(FDRE) 1 year, No.1,(Addis Abeba_August 1995),46; Temesgen Gebeyehu, Peasants, land reform and property right in Ethiopia: The experience of Gojjam Province, 1974 to 1997,(2013),145.

${ }^{x x}$ Yigremew Adal, "Some Queries about the Debate on Land Tenure in Ethiopia" in Mulat and Tassew(eds) proceedings of the Tenth Annual conference on Ethiopian Economy, Ethiopian Economic Association/ECA/ (2001),56;Dessalegne Rahmato, 'Land Policy in Ethiopia at the Cross roads.” 
In Dessalegne and Taye ( ed. ) Land Tenure and Land policy in Ethiopia after the Derg , Proceeding of the Second Workshop of the land Tenure Project, (Addis Abeba University, October 1994:No.8),8;Ethiopian Economists' Association/EEA/Ethiopian Economic policy Research /EEPR/ Land Tenure and Agricultural Development in Ethiopia ,(United Printers: Addis Abeba 2002),28;Tafesee Olika, "Ethiopian politics of Land Tenure Policies under three Regimes; a Carrot and Stick Ruling Strategy.” In Alexander, Kassahun and Yonas (ed.) Ethiopia Politics, Policy Making and Rural Development (Addis Ababa University Press: Addis Ababa,2006),11.

xxi Dessalegne Rahmato,(1994),8-9.

xxii Bruce,(1993),23

xxiii FDRE Rural Development Strategy,(1998),30-35.

xxiv Samuel Gebre Selasie(2006), 45.

${ }^{x \times v}$ Desalegne Rahmato,(1994),8-11.

${ }^{x x v i}$ FDRE constitution (1995), 45; 'No Loans with Land ownership Certificate as collateral’ The Reporter (Amharic, private News Letter (Hidar 2000 E.C) vol.13, No 12.

xxvii Temesgen Gebeyehu,(2013),152;Getie (1997) gives highlights about details of the land redistribution program in Gojjam;EEA/EPRI,(2002),18-19; Samuel(2006),45.

xxviii Ibid;EEA(2002),23-25

xxix Desalegne Rahmato, 'The Land Question and Reform Policy; Issue for Debate’ Dialogue Third Series, Vol.1, No 1(1992)43-57.

${ }^{x x x}$ Desalegne Rahmato, 'From Heterogeneity to homogeneity Agrarian class Structure in Ethiopia since the 1950s in Desalegne and Taye(ed.).Land and the Challenges of Sustainable Development in Ethiopia, Conference Proceeding (Forum for Social Studies :Addis Ababa,2006),3.

xxxi The FDRE Rural Development Strategy; written in Amharic, (1998 E.C),27-28.

xxxii Yigremew Adal,(2001),60-64;Allan Hoben,(2002),15.

xxxiii J.W.Bruce, Allan Hobben and Desalegne Rahmato, After the Derg: An Assessment of Rural Land tenure issues in Ethiopia (Institute of Development and Research and Land Tenure Centre,1993),41-44.

xxxiv Samuel Gebre Selasie,(2006),78; Daniel Kassahun, "Towards the

Development of Differential Land Taxation in Ethiopia” .in Attilo, etal(eds.) Ethiopia; Politics ,Policy making and Rural Development .(Addis Ababa University Press, Addis Ababa,2006),108.

${ }^{x x x v}$ Fantu Cheru, Designing Structural Adjustment program; Reconstruction, Rehabilitation and Long term Transformation. in Abebe Zegeye and Pausewang, Siegfred (eds.) Ethiopia in Change ;peasantry ,Nationalism and Democracy ,(British Academic Press:London,1994),128-151.

xxxvi M.A Marqnardt ," Global Experiences in Land Registration and Titling.” In Solomon Bekure etal (eds.) Standardization of Rural Land Registration and Cadastral Survey Methodologies in Ethiopia, Proceedings of a National Conference ,(Addis Ababa,2006),15.

xxxvii Klous Deininger, "Land Policies for Growth and Poverty Reduction" A World Bank policy Research Report, (Oxford University Press; Oxford 2003), 54.

xxxviii Allan Hoben,(2002),30-31.

xxxix Dessalegne Rahmato,(1994),10-14

${ }^{x l}$ EEA/EPRI (2002),40-49.

${ }^{x l i}$ Allan Hoben,(2002),28-29 